\section{Presowing Seed Treatments to Enhance Supersweet Sweet Corn Seed and Seedling Quality}

\author{
Carlos A. Parera and Daniel J. Cantliffe \\ Horticultural Sciences Department, University of Florida, Gainesville, \\ FL 32611
}

Additional index words. Zea mays, shrunken-2, solid matrix priming, fungicides, presowing treatments

\begin{abstract}
Poor emergence and low seedling vigor are characteristics of many supersweet sweet corn (Zea mays L.) cultivars carrying the shrunken-2 (sh2) gene. Four sh2 sweet corn cultivar seeds ['How Sweet It Is' (HSII), 'Crisp N' Sweet 711' (CNS-711), 'Sweet Belle' (SB), and 'Dazzle' (DZ)] were solid-matrix-primed (SMP), SMP with sodium hypochlorite $\left(\mathbf{S M P}_{\mathrm{c}}\right)$, treated with a fungicide combination (F) (Imazalil + Captan + Apron + Thiram), or primed with the aforementioned fungicides $\left(\mathbf{S M P}_{\mathrm{f}}\right)$. The seed treatments were tested in the laboratory and the field. Seed imbibition and leachate electrical conductivity were lower in SMP seeds than in nonprimed seeds. In the field, emergence percentage and rate of CNS-711 and SB (high-vigor seeds) were not improved by the seed treatments compared to the nontreated seeds. Emergence percentage and rate of HSII and DZ (considered lowvigor seeds) were improved as a result of $\mathrm{SMP}_{\mathrm{c}}, \mathrm{SMP}_{\mathrm{f}}$, or $\mathrm{F}$ treatments compared to nonprimed seeds. Compared to the $\mathbf{F}$ treatment, the $\mathbf{S M P}_{\mathrm{cl}}$ presowing treatment increased DZ seedling emergence rate and percentage. The combined SMP and seed disinfection via $\mathrm{NaOCl}$ seems to be a promising fungicide seed-treatment substitute that improves the stand establishment and seedling vigor of $s h 2$ sweet corn cultivars. Chemical names used: 1-[2-(2,4-dichlorophenyl)-2-(2-propenyloxy)ethyl]-1 $\mathrm{H}$ imidazole (Imazalil); $\mathrm{N}$ [(trichloromethyl)thio]-4-cyclohexene-1,2-dicarboximide(Captan); $\quad N$ - (2,6dimethylphenyl)- $N$-(methoxyacetyl)alanine methyl ester (Apron); tetramethylthiuram disulfide (Thiram).
\end{abstract}

Kernels of supersweet sweet-corn hybrids carrying the shrunken-2 (sh2) mutation have excellent eating quality and long shelf life because of high-sugar maintenance in the endosperm. Although the marketable characteristics and the demand for the product are high, seedling emergence and vigor are negatively affectedly the mutation (Cantliffe et al., 1975).

Poor sh 2 sweet corn emergence has been associated with high susceptibility to seed and soilborne pathogens (Berger and Wolf, 1974; Cantliffe et al., 1975). Fungi isolated from supersweet corn seeds include Rhizopus sp., Fusarium spp., Penicillium spp., and Pythium spp. (Pieczarka and Wolf, 1978). Styer and Cantliffe (1984) found sh2 sweet corn kernels heavily infected by Fusarium moniliforme early in development. The fungus was located in pericarp crevices and eventually moved into the endosperm. Fungicide seed treatments improved stand establishment and seedling uniformity in supersweet sweet corn seeds (Cantliffe et al., 1975; Cantliffe and Bieniek, 1988; Pieczarka and Wolf, 1978). To avoid pesticide dependence for seed treatment, alternative methods are necessary to control pathogens.

Received for publication 25 June 1993. Accepted for publication 28 Sept. 1993, Florida Agr. Expt. Sta. Journal Series no. R02820, The cost of publishing this paper was defrayed in part by the payment of page charges. Under postal regulations, this paper therefore must be hereby marked advertisement solely to indicate this fact.
Solid matrix priming (SMP) is a presowing seed treatment that has increased germination rate and percentage in many species (Kubik et al., 1988; Taylor et al., 1988). SMP combined with sodium hypochlorite $\left(\mathrm{NaOCl} ; \mathrm{SMP}_{\mathrm{cl}}\right)$ has improved sh2 sweet corn emergence percentage and rate under stressful conditions (Parera and Cantliffe, 1992). Our objective was to compare the $\mathrm{SMP}_{\mathrm{c}}$ effects to the fungicide treatment on field emergence percentage and rate of $\operatorname{sh} 2$ sweet corn cultivars.

\section{Materials and Methods}

Primary and fungicidal treatments. Pour sh2 sweet corn hybrids were used in this study: 'Crisp N' Sweet 711' (CNS-711) and 'How Sweet It Is' (HSII) (both, Crookham Seed, Caldwell, Idaho) and 'Sweet Belle' (SB) and 'Dazzle' (DZ) (both, Asgrow Seed, Twin Falls, Idaho). Before and after treatment, the seeds were stored at $15 \mathrm{C}$ and $45 \%$ relative humidity (RH).

Using Parera and Cantliffe's (1991) method, seeds $(9 \mathrm{~g})$ were mixed with $27 \mathrm{~g}$ calcined clay (Emathlite; Mid-Florida Mining, Lowell, Fla.) and $14 \mathrm{ml} 0.1 \%$ (v/v) NaOCl solution $\left(\mathrm{SMP}_{\mathrm{cl}}\right)$ or $14 \mathrm{ml}$ fungicide solution $\left(\mathrm{SMP}_{\mathrm{f}}\right)$. The fungicide solution $(\mathrm{F})$ was comprised of Imazalil $(0.65 \mathrm{ml} / \mathrm{kg}$ seed $)$, Captan $(2.0 \mathrm{ml} / \mathrm{kg}$ seed), Apron $(0.5 \mathrm{ml} / \mathrm{kg}$ seed $)$, and Thiram $(3.3 \mathrm{ml} / \mathrm{kg}$ seed). The mix was placed in a container at $5 \mathrm{C}$ for $6 \mathrm{~h}$, then moved to $25 \mathrm{C}$ for $66 \mathrm{~h}$ under continuous rotation $(20 \mathrm{rpm})$. After treatment, the seeds were dried at $25 \pm$
$1 \mathrm{C}$ and $45 \% \mathrm{RH}$ to their initial $6 \%$ moisture content. Nonprimed seeds ( $200 \mathrm{~g}$ ) were soaked for 2 min in 1 liter $F$ solution and then dried as previously indicated.

The laboratory tests and field experiment were conducted as a randomized completeblock design, with treatments replicated four times. Percentage data were converted and analyzed as the square-root arcsin transformation. We performed an analysis of variance on each measured variable and separated means by least significant difference test at $P \leq 0.05$.

Seed imbibition and leachate electrical conductivity. Nontreated seeds (25) of each cultivar were soaked in $25 \mathrm{ml}$ of distilled water at $25 \mathrm{C}$. Imbibition was determined gravimetrically at $2,4,6$, and $8 \mathrm{~h}$ by measuring the increase in seed fresh weight after blotting surface water from the seeds. Leachate electrical conductivity of soak water, expressed as deciSiemens per meter per gram of seed (Parera, 1992), was measured each hour for up to $4 \mathrm{~h}$ using a conductivity meter (Lecto Mhometer; Lab-Line Instruments, Melrose Park, Ill.).

\section{Results and Discussions}

Field seedling emergence. Treated seeds were evaluated in a field trial (planted 14 Mar. 1990) at the Institute of Food and Agricultural Sciences Horticultural Unit in Gainesville, Fla., on Arredondo fine sand soil (loamy, siliceous, hyperthermic Grossarenic Palenundult). Plot length was $7.6 \mathrm{~m}$ on beds with 1.2$\mathrm{m}$ centers. Each bed was $0.7 \mathrm{~m}$ wide and $0.2 \mathrm{~m}$ high. Two seeds were placed $4 \mathrm{~cm}$ deep every $30 \mathrm{~cm}$ in each plot (50 seeds per plot). Overhead sprinkler irrigation was applied as needed. Emergence rate index (ERI) (Shmueli and Goldberg, 1971) and percentage emergence were calculated from daily counts of seedlings emergence for 14 days after planting.

Regardless of cultivar, the primed seeds imbibed less water during the first $8 \mathrm{~h}$ of imbibition than nonprimed seeds (Table 1). Also, leachate electrical conductivity was less from primed seeds than nonprimed seeds regardless of cultivar. DZ and HSII had the highest water uptake and seed leachate electrical conductivity and were regarded as low-

Table 1. Imbibition after $8 \mathrm{~h}$ and leachate electrical conductivity after $4 \mathrm{~h}$ soaking of primed (SMP) and nonprimed (NP) seeds of four sweet corn cultivars.

\begin{tabular}{lcc}
\hline \hline & $\begin{array}{c}\text { Imbibition } \\
\text { (\% fresh wt } \\
\text { increase) }\end{array}$ & $\begin{array}{r}\text { Conductivity } \\
\left(\mathrm{dS} \cdot \mathrm{m}^{-1} \cdot \mathrm{g}^{-1}\right)\end{array}$ \\
Treatment & & \\
\hline Seed treatment (ST) & 59 & 9.9 \\
SMP & 66 & 12.8 \\
NP & $* *$ & $* *$ \\
Significance & & \\
Cultivar (C) & & 5.1 \\
Crisp N'Sweet 711 & 152 & 11.2 \\
How Sweet It Is & 73 & 7.4 \\
Sweet Belle & 55 & 10.4 \\
Dazzle & 68 & 3.1 \\
LSD $_{0.05}$ & 6 & $\mathrm{NS}$ \\
ST $^{2} \mathrm{C}$ & $\mathrm{NS}$ & \\
\hline
\end{tabular}

${ }^{2}$ Significant or nonsignificant at $P \leq \overline{0.01 \text {, respec- }}$ tively. 
Table 2. Seed treatment effects on percent emergence and emergence rate index (ERI) of 'Crisp N' Sweet 711' (CNS-711), 'Sweet Belle' (SB), 'How Sweet It Is' (HSII), and 'Dazzle' (DZ) sweet corn cultivars planted 14 Mar. 1990 in Gainesville, Fla.

\begin{tabular}{|c|c|c|c|c|c|c|c|c|}
\hline \multirow[b]{3}{*}{ Treatment $^{2}$} & \multicolumn{4}{|c|}{ ERI } & \multicolumn{4}{|c|}{ Emergence (\%, angular transformation } \\
\hline & \multicolumn{4}{|c|}{ Cultivar } & \multicolumn{4}{|c|}{ Cultivar } \\
\hline & CNS-711 & HSII & SB & $\mathrm{DZ}$ & CNS-711 & HSII & SB & DZ \\
\hline $\mathrm{SMP}_{\mathrm{cl}}$ & 231 & 145 & 136 & 176 & $83[66]$ & $50[45]$ & $59[50]$ & $71[57]$ \\
\hline $\mathrm{SMP}_{f}$ & 230 & 148 & 137 & 178 & $83[66]$ & $.55[48]$ & $58[50]$ & $57[49]$ \\
\hline $\mathrm{F}$ & 193 & 132 & 152 & 107 & $79[63]$ & $58[50]$ & $72[59]$ & $35[36]$ \\
\hline NP & 160 & 56 & 124 & 90 & $66[54]$ & $22[20]$ & $48[44]$ & $34[36]$ \\
\hline \multicolumn{9}{|l|}{ Significance } \\
\hline Cultivar $\times$ treatment & & & ** & & & & & ** \\
\hline LSD $\quad$. & & 40 & & & & [18] & & \\
\hline
\end{tabular}

${ }^{2} \mathrm{SMP}_{\mathrm{cl}}=$ solid matrix priming with $\mathrm{NaOCl} ; \mathrm{SMP}_{\mathrm{f}}=$ solid matrix priming with fungicides; $\mathrm{F}=$ fungicide combination treatment (nonprimed); and $\mathrm{NP}=$ nonprimed seeds.

"Significant at $P \leq 0.01$

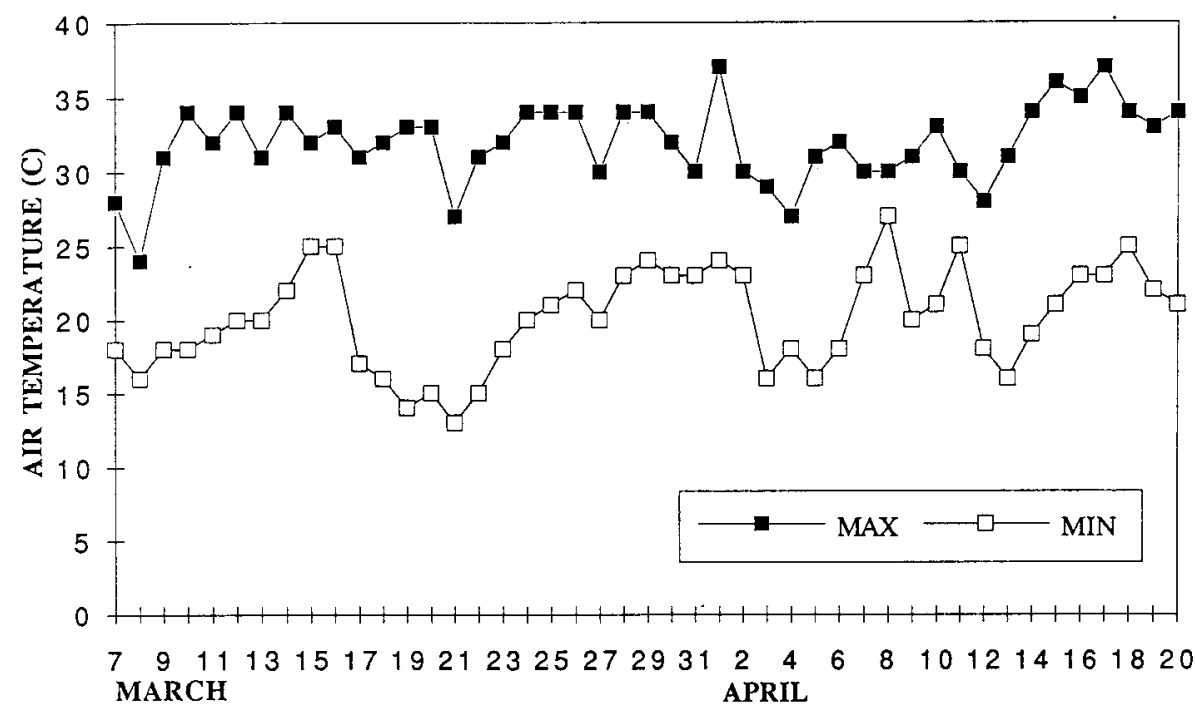

Fig. 1. Daily maximum and minimum temperatures before and during field experiment planted 14 Mar. 1990.

vigor seeds (Table 1). Parera and Cantliffe (1991) have shown high negative correlations between $s h 2$ sweet corn seed imbibition or leachate electrical conductivity and field emergence.

Emergence percentages of SB and CNS-711 were unaffected by seed treatments. Compared to the nonprimed seeds, the SMP treatments $\left(\mathrm{SMP}_{\mathrm{cl}}\right.$ and $\left.\mathrm{SMP}_{\mathrm{f}}\right)$ increased the germination rate of CNS-711 (higher ERI) but not of SB (Table 2). In DZ, both percent emergence and ERI were higher for SMP and $\mathrm{SMP}_{\mathrm{f}}$ seeds than for $\mathrm{F}$ seeds or nonprimed seeds. DZ seeds primed with $\mathrm{NaOCl}$ had higher percent emergence than seeds receiving For $\mathrm{SMP}_{\mathrm{f}}$ treatments. Treated HSII seeds had higher emergence rate and percentage than nonprimed seeds.

Without seed treatment, low seed vigor and seedborne disease infection can occur, leading to poor seedling emergence and low stand establishment in many sh2 sweet corn cultivars. The SMP treatment characteristics permit incorporation of various materials, such as biological agents (Harman and Taylor, 1988) or $\mathrm{NaOCl}$ (Parera and Cantliffe, 1991 ) during priming. Adding $\mathrm{NaOCl}$ during SMP improved seedling emergence percentage and rate, especially for the less vigorous seed lots DZ and HSII. Reduced organic constituent loss in the leachate as a result of SMP might further reduce substrate availability for pathogen development in less vigorous seed lots.

Emergence of sh2 sweet corn is adversely affected by extremes in temperature immediately after planting. Low temperatures reduce seed germination rates and ultimately can increase seed leakage, thereby promoting deterrence of soilborne and seedborne pathogens (Parera and Cantliffe, 1992). Cantliffe and Bieniek (1988) and Parera and Cantliffe (1992) showed that $s h 2$ seedling emergence was severely reduced by high soil temperatures during the germination-seedling emergence period. Also, high temperatures have been associated with increased pathogen growth prolif- eration on and around $\operatorname{sh} 2$ seeds (Styer and Cantliffe, 1984). In our experiments, daily maximum air temperatures $1 \mathrm{~m}$ above the seed bed remained unusually high before and after planting (Fig. 1); this probably resulted in the poor emergence of nonprimed seeds or seeds not treated with a fungicide combination in our experiment.

From our laboratory and field results, we conclude that the SMP $+\mathrm{NaOCl}$ seed treatment improves stand establishment (percentage and rate) and seedling vigor in several sh2 sweet corn cultivars. Few differences in seedling emergence percentage or rate were observed between SMP treatment and $\mathrm{SMP}_{\mathrm{f}}$ or $\mathrm{F}$ treatment. The SMP treatment with $\mathrm{NaOCl}$ may bean effective replacement for fungicide seed treatments of sh2 sweet corn cultivars, especially when a multi-fungicide treatment otherwise would be used.

\section{Literature Cited}

Berger, R.D. and E.A. Wolf. 1974. Control of seedborne and soilborne mycoses of 'Florida Sweet' corn by seed treatment. Plant Dis. Rptr. 58:922-923.

Cantliffe, D.J. and M. Bieniek. 1988. Improving plant stands of supersweet corn by seed treatment. Proc. Fla. State Hort. Soc. 101:372-376.

Cantliffe, D.J., E.A. Wolf, and J.M. White. 1975 Improved germination and plant stand of 'Florida sweet' corn by seed treatment. Proc. Fla. State Hort. Soc. 88:170-173.

Harman, G.E. and A.G. Taylor. 1988. Improved seedling performance by integration of biological control agents at favorable $\mathrm{pH}$ levels with solid matrix priming. Phytopathology 78:520 525.

Kubik, K.K., J.A. Eastin, J.D. Eastin, and K.M. Eskridge. 1988. Solid matrix priming of tomato and pepper. Proc. Intl. Conf. Stand Establishment Hort. Crops p. 86-96.

Parera, C.A. 1992. Seed vigor and germination of shrunken-2 maize. PhD Diss., Univ. of Florida, Gainesville.

Parera, C.A. and D.J. Cantliffe. 1991. Improved germination and modified imbibition of shrunken-2 sweet corn by seed disinfection and solid matrix priming. J. Amer. Soc. Hort. Sci. 116:942-945.

Parera, C.A. and D.J. Cantliffe. 1992, Enhanced emergence and seedling vigor inshrunken-2 sweet corn via seed disinfection and solid matrix priming. J. Amer. Soc. Hort. Sci. 117:400-403.

Pieczarka, D.J. and E.A. Wolf. 1978. Increased stand of 'Florida Staysweet' corn by seed treatments with fungicides. Proc. Fla. State Hort. Soc. 91:290-291.

Shmueli, M. and D. Goldberg. 1971. Emergence, early growth, and salinity of five vegetable crops germinated by sprinkle and trickle irrigation in an arid zone. HortScience 6:563-565.

Styer, R.C. and D.J. Cantliffe. 1984. Infection of two endosperm mutants of sweet corn by Fusarium moniliforme and its effect on seedling vigor. Phytopathology 74:189-194.

Taylor, A.G., D.E. Klein, and T.H. Whitlow. 1988. SMP: solid matrix priming of seeds. Scientia Hort. 37:1-11. 